\title{
INSTABILITY AND ITS GOVERNMENT REGULATION
}

\author{
Taisiia Bondaruk', Nataliia Melnychuk ${ }^{2}$ \\ National Academy of Statistics, Accounting and Audit, Ukraine \\ Igor Bondaruk ${ }^{3}$ \\ Pavlo Tychyna Uman State Pedagogical University, Ukraine
}

\begin{abstract}
The research proves that the breach of stability in the economic system, as well as the appearance of the instability phenomenon, arise immediately after losing some balance between the population and government. As the result, the development of the institute of the state with the proper regulative set of instruments, as well as the extending of the international relations can take the instability from micro- and mezo-levels to macro- and meta-levels. It analyses and defines the concepts: state and budget instability. Particularly, the definition of the political, financial, social, as well as economic instabilities is enhanced. Key problems of state instability, which may occur as a result of unsuccessful government regulation and ineffective management with budgetary funds, are distinguished. The aim of the article is to develop the concept of instability and its types, to determine the causal interconnection for distinguishing the problems of state instability that may influence the state economic development. The target of the research is the theoretical and methodological bases of the instability occurrence and its state regulation. The research methodology. According to the aim set, we determined the methodological basis of the research: the abstract-logical method - to sum up the theoretical basis of instability; the systemic analysis - to characterize the types of instability; the analysis and synthesis - to estimate the influence of the state instability on the state economic development; the graphics method - to demonstrate final results of the research; economic-statistic - to define the problems of the state instability that may influence the state economic development. Conclusions. It has been proved that instability is the condition of the system that is characterized by the variation that happened through breaking the existing interconnection in it. The instability is that basic feature that characterizes all social and economic processes. The danger occurs when the level of instability in the state exceeds some standards. We determined political, economic, social, financial and budget instabilities as well as gave the authors' definition of these phenomena after distinguishing the theoretical bases of instability. It has been proved that the government instability consists of these types. We have proposed to determine the government instability as the condition of the state characterized by the constant changes in political, economic, social, financial, and budget spheres because of the factors that influence changes in its structure and functional characteristics accompanied by the phenomena that have a negative influence on the state development in general. The indexes analysis of the international rating and collation of its results with the graphic interpretation of the government instability have helped to prove that Ukraine has the low level of the government instability. It has been classified into five groups of problems in the economy. The analysis of the existing problems, the identification of their influence on the instabilities, as well as the clarification of their interconnection gave the possibility to study the influence of the unsuccessful state regulation on the management with budgetary funds.
\end{abstract}

Key words: regulation, instability, Ukraine, state instability, problems of instability.

JEL Classification: G28, G38

\footnotetext{
Corresponding author:

${ }^{1}$ Department of Finances, Banking, and Insurance, National Academy of Statistics, Accounting and Audit. E-mail: bondaruk23@ukr.net

${ }^{2}$ Department of Finances, Banking, and Insurance, National Academy of Statistics, Accounting and Audit.

E-mail: natasha shevchuk 2012@ukr.net

${ }^{3}$ Department of Marketing, Management and Business Administration, Pavlo Tychyna Uman State Pedagogical University.

E-mail: bondaruk_igor@ukr.net
} 


\section{Introduction}

The breach of stability in the economic system, as well as the appearance of the instability phenomenon, arises immediately after losing some balance between the population and government. The government is not fairly often able to conduct policy that reflects the population needs. Consequently, the disappointment and indignation are inevitable (2011, p. 69). As the result, the development of the institute of the state with the proper regulative set of instruments, as well as the extending of the international relations can take the instability from micro- and mezo-levels to macro- and meta-levels (Khonstantynova, 2013).

This problem draws the experts' attention from different countries. The leading economists and researchers (J. Canes, I. Fisher, W. Roger, S. Shroeder, P. Hyman, K. Juselius, T. Lux, Br. Sloth, and V. Heiets) study the problem of instability and its state regulation. However, despite constant researchers' and experts' attention to this sphere, it is impossible to avoid the instability. The problems that are worth additional studying are as following: the lack of systematic view with regard to the nature of instability and its types, the recognition of the problems that may occur because of its existence. This will help to analyse types of instability that may happen and problems they may bring.

The aim of the article is to develop the concept of instability and its types, to determine the causal interconnection for distinguishing the problems of state instability that may influence the state economic development.

According to the aim of the research, we achieved the following objectives: to study the basic nature of instability; to determine its types and give own definition; to prove the interconnection between different types of instability; to systematize problems of instability that may occur in the sphere of state regulation.

The target of the research is the theoretical and methodological bases of the instability occurrence and its state regulation.

The research methodology. According to the aim setting, we determined the methodological basis of the research: the abstract-logical method - to sum up the theoretical basis of instability; the systemic analysis to characterize the types of instability; the analysis and synthesis - to estimate the influence of the state instability on the state economic development; the graphics method - to demonstrate final results of the research; economic-statistic - to define the problems of the state instability that may influence the state economic development.

The novelty of the research can be concretized in the following statements:

- it has been analysed and determined the concepts: the state instability - the condition of the state characterized by the constant changes in political, economic, social, financial and budget spheres because of the factors that influence changes in its structure and functional characteristics accompanied by the phenomena that have a negative influence on the state development in general; budget instability - the breach of budget system functioning caused by synergetic influence of outer and inner disproportion at all its levels and it leads to the unpredictable phenomena that have the negative influence on the condition of the formation and use of budgetary funds;

- it has classified the main problems of state economic development according to the types of state instability (political, economic, social, budget) accompanied by the study of the influence of the unsuccessful state regulation on the management with budgetary funds.

\section{The statement of basic materials}

The primary explanation of the instability differs considerably from the present one. In the last century, J. Canes proposed to use this notion. He mentioned that the instability is one of the inner characteristics of the market economy. The theory of J. Canes says that saving is the cause of instability and insufficiency of the effective demand for providing full employment, as high incomehunting with the purpose to attract savings can create the speculative motive (Canes, 1993). We agree with V. Heiets who notes that the instability is the condition of the state characterized by the variations that happened through breaking the existing interconnection in it. It is the immanent peculiarity of the economic development (Heiets, 2000).

The instability is such a characteristic that reflects social and economic processes. It can be explained primarily by the fact that the economic development is unstable, has the cyclic character. The instability may occur in different types. The existence of the unstable elements cannot threaten the state's life. The danger may happen only in the case when the level of state instability exceeds certain standards.

In today's life, most of the foreign and national researchers distinguish the following types of instability: financial, economic, political, as well as social. While analysing references, we have defined the financial instability as the main objective for most of the researches (Table 1).

As it is seen, (Table 1) different researchers have analysed the financial instability. Having studied all their approaches, we conclude that all of the presented definitions are worth paying our attention. In fact, we can divide them into four groups. The first group comprises the definitions that reflect the positive character of the instability. The researchers of this group consider the instability to be the uncertainty that is natural for the certain period of the economic development (I. Popov, P. Hyman, D. Colander, H. Follmer, A. Haas, 
M. Goldberg, K. Juselius, A. Kirman, T. Lux, Br. Sloth, A. Khirman, D. Collander, H. Phelmer, F. Haas). The second group of the researchers characterizes the instability as the uncertainty that leads to negative consequences (I. Fisher, H. Shynasy, A. Crockett, W. Roger, S. Shroeder, P. Trunin, M. Khamenskyh). The third group comprises researchers who think that the financial instability is only connected with the problems in the investment sphere (F. Mishkin, V. Burlachkov, J. Guttentag, R. Herring). Definitions that do not explain completely the concept of the financial instability refer to the fourth group - H. Shynasy, Z. Vasylchenko.

Thus, we consider to propose own definition of the financial instability. The financial instability is the condition of the market economic system that changes its outer and inner characteristics under the influence of objective and subjective factors, is characterized by the crises occurrence that influences the financial system badly. The financial instability may occur as: declining deposits, selling up for the reduced price, output reducing, the growth of bankrupt enterprises and others.
The concept of economic instability in most cases is identified with the macro-economic instability (the loss of mobility, dynamic, and flexibility of the economic system, incapacity to be adapted conveniently and completely to the changes of inner conditions of its functioning and environment (Klymko, Nesterenko, Khanishchenko, 1999) and the economy instability (the lack of full employment guaranteeing, the stable level of prices, inflation (Sumarokov, 1996); economy that is considered to be in the state of imbalance as a result of inner and outer factors and is connected with inflationary processes, too expensive credits (Hrabchuck, 2012); incompleteness of important processes in market transformations, narrowness of domestic market, great dependence on a foreign market, the low level of economic sovereignty in the conditions of the financial sector's growing in further prospects without the real one, the backwardness of the economic structure and its power consumption in abundance (Rudnytska, 2011). We fully agree with such statements. However, we consider proposing own

Table 1

Approaches to the definition of the economic concept of "financial instability"

\begin{tabular}{|c|c|}
\hline Author & Definition \\
\hline I. Fisher, 1993 & The negative dynamics of fundamental indexes. \\
\hline H. Shynasy, 2004 & The situation in the financial market that prevents or threatens the economic activities. \\
\hline A. Crockett, 1997 & $\begin{array}{l}\text { The situation when the prices variations of financial assets or the inability of the financial } \\
\text { institutions to perform their contractual obligations are making worse the economy's functioning. }\end{array}$ \\
\hline I. Popov, 2012 & $\begin{array}{l}\text { 1) An ability of the financial system to perform effectively its financial functions during the long- } \\
\text { lasting period and in conditions of uncertainty; 2) a certain condition of the system's general } \\
\text { stability and its particular elements. }\end{array}$ \\
\hline W. Roger, 2008 & $\begin{array}{l}\text { The situation characterized by three main criteria: } 1 \text { ) prices for some key financial assets are } \\
\text { declined considerably from its fundamental bases; 2) functioning of the credit market is broken, } \\
\text { consequently, it is declined from the normal level of aggregate expenditure. }\end{array}$ \\
\hline Z. Vasylchenko, 2005 & $\begin{array}{l}\text { The complex characteristic of the bank system condition that distorts or implements partially its } \\
\text { concept and the role in the state economic system, as well as performs its functions inadequately } \\
\text { or ineffectively. The incapacity to maintain the balance and to renew the inner condition after } \\
\text { outer disturbances or the strengthening of the disproportions, any deviation from safe parameters } \\
\text { caused by crisis phenomena (economy decrease, financial crisis, economic transformation and } \\
\text { others) are manifested. }\end{array}$ \\
\hline F. Mishkin, 1996 & $\begin{array}{l}\text { The situation when the financial system is under shocks accompanied by such a process when it is } \\
\text { unable to transform savings into investments. }\end{array}$ \\
\hline S. Shroeder, S. Schroeder, 2009 & $\begin{array}{l}\text { A special occasion as the consequence of exogenous shocks, markets imperfection and price } \\
\text { instability. }\end{array}$ \\
\hline V. Burlachkov, 2009 & $\begin{array}{l}\text { The situation when the financial system is under shocks and process when it is unable to transform } \\
\text { savings into investments. }\end{array}$ \\
\hline P. Hyman, 1992 & A characteristic trait of the normal development of the capitalist economy. \\
\hline $\begin{array}{l}\text { D. Colander, H. Follmer, A. Haas, } \\
\text { M. Goldberg, K. Juselius, A. Kirman, } \\
\text { T. Lux, Br. Sloth, } 2009\end{array}$ & $\begin{array}{l}\text { It is immanent in the market economic system and admits to some extents the crisis renovation. } \\
\text { The level of instability is connected to the financial innovations and the intensification of } \\
\text { interconnections between financial markets in the world. }\end{array}$ \\
\hline J. Guttentag, R. Herring, 1984 & $\begin{array}{l}\text { It is caused by the asymmetry between creditors' information and debtors as a result of the } \\
\text { uncertainty of the return from the investment projects that intensifies the instability in the real } \\
\text { economic sector because of the refusal to give money to debtors. }\end{array}$ \\
\hline P. Trunin, M. Khamenskyh, 2007 & $\begin{array}{l}\text { Such problems in the financial system of the state (or in total) which have the considerable } \\
\text { negative influence on the economic activity. }\end{array}$ \\
\hline $\begin{array}{l}\text { A. Khirman, D. Collander, H. Phelmer, } \\
\text { A. Haas, } 2010\end{array}$ & eans that the economic system admits the crisis renovation to some extents. \\
\hline
\end{tabular}


point of view. Economic instability is the lack of balance in the economic system. It causes the violation of structural elements in the economic system's equilibrium that brings changes in the inner peculiarities of the system itself. The case of economic instability can be found in hryvnia devaluation, escalation of inflation, stagnation in manufacturing, the growth of price goods and services, as well as black economy, low salaries, corruption.

The definition of the concept of the political and social instability in different researches has not been found. Therefore, we propose own conception of the phenomenon.

The political instability can be considered as the condition of the political system of the state characterized by the constant changes in its structural elements. It is unpredictable, as well as hard to prognosticate. The aforementioned characteristics develop negative features of the system. The striking example of the political instability can be perestroika promoted by Mikhail Gorbachev in early 1990s. In 2014, the fundamental base of the political conflict in Ukraine was the failure of trust to the state government.

The social instability is the condition of the unbalance in the social sphere, characterized by the variations in social indexes and the lack of the government bodies to react to changes on-the-fly. These changes break the interconnection in the social sphere. The examples of the social instability in Ukraine can be migrations of able-bodied Ukrainians, the low level of proprietary security, the reduction of the purchasing power of the population, unemployment, social differentiation, quick growth of the poverty, economic and inner-cultural crisis in the society.

However, all types of instability are interconnected and influence each other. Every type of instability has its forms of manifestations that reflect negatively in the state's development. The attempt of the government authorities to interfere in the economic development has the sporadic character. The use of all forms of government regulation has anti-effect. The situation is difficult as not only the fact that Ukraine is under the conditions of instability but also the approaches to the regulations to be used (they were practiced in the period of the soviet totalitarian system). Consequently, Ukraine does not have the successful system of the state regulation and this fact leads to the inefficiency in financial recourses management.

Taking into the consideration the fact that instability is characterized by the uncertainty and unpredictability we propose new definition "government instability". This will help to research the government instability and its regulation from the point of its systematicity and will influence the effectiveness of the government regulation in general.

We propose to define the government instability as the condition of the state characterized by the constant changes in the political, economic, social, financial, and budget spheres under the influence of factors that may change its structure and functional characteristics, as well as caused by different phenomena that influence badly the state development in general.

The graphic chart of the government instability can show more detailed characteristics of its nature (Chart 1).

The proposed interpretation helps to define the level limit between the government stability and instability, to distinguish between different levels of the government instability: high, optimal, low, critical.

The area of stability is the high level of socioeconomic, as well as the political development of the state. The utmost zone reflects the optimal level of the

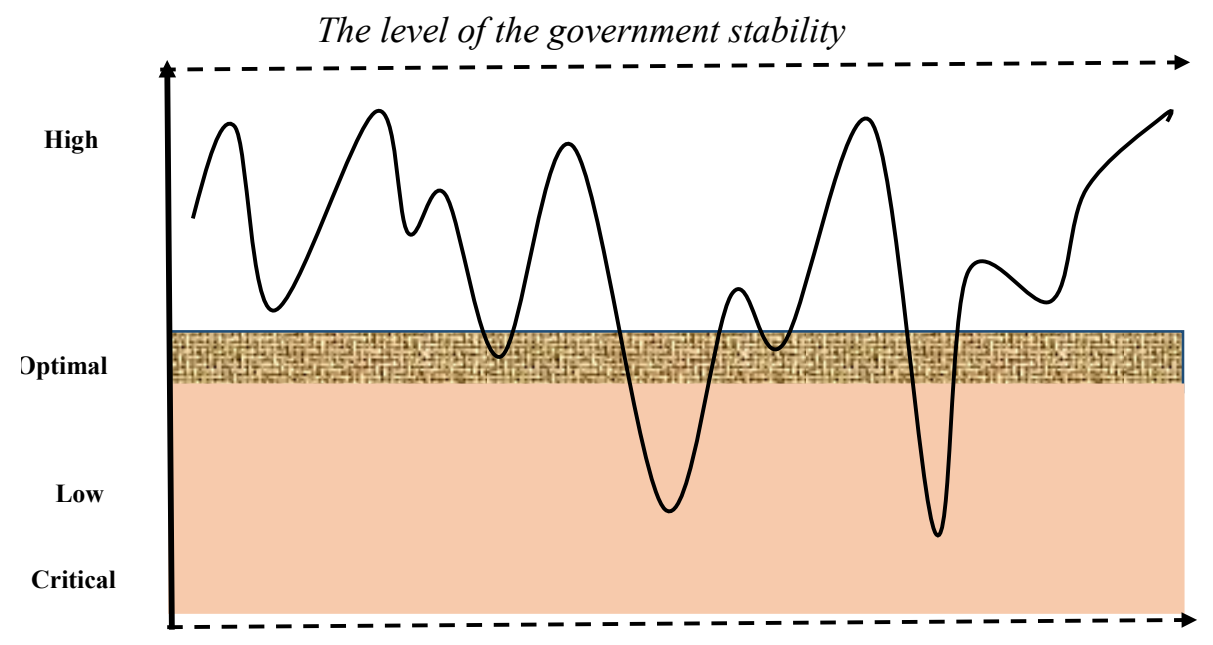

The level of the government instability

Chart 1. The graphic interpretation of the government instability

Source: proposed by the authors 
development. It means a level that is safety for every state. The low level of the government stability reflects the critical point. It proves the great possibility of the government instability. The critical level is characterized by the schedule of government stability. It deflects down the utmost zone. The aforementioned facts prove that the state exhausts "the strength reserve" and it may lead to the government instability.

The main features of the government instability in Ukraine are:

- the dysfunction of the government authority - the state does not have the power to protect its citizens from the violence - the conflict in the Eastern part of Ukraine; - the dysfunction to provide welfare - the state cannot guarantee that all citizens have the access to the political, economic, and social weals;

- the lack of legitimacy - the state is not sufficient enough with legitimacy, it has the limited support of the population.

Taking into consideration the main features of the government instability, we propose to define the notion "budget instability". It will help to distinguish main problems that may occur in the budget sphere as a result of the instability.

It is supposed to think that the budget instability is the violation of budget system functioning caused by the synergetic influence of inner and outer disproportions at all its levels and it leads to the unpredictable circumstances that have the negative influence on the formation condition and the use of budgetary funds.

The level of government regulation's effectiveness depends greatly on the availability of the necessary budgetary funds. Hence, there is the understanding of the role and importance of the government regulation of the budget instability. This is one of the main priorities of the government authorities' activities and the necessary condition for the effective budget management (Chart 2).

The state instability can also be characterized with the help of indexes determined by the international ratings (Chart 3).

It is considered that the government instability is possible to characterize with the help of the following

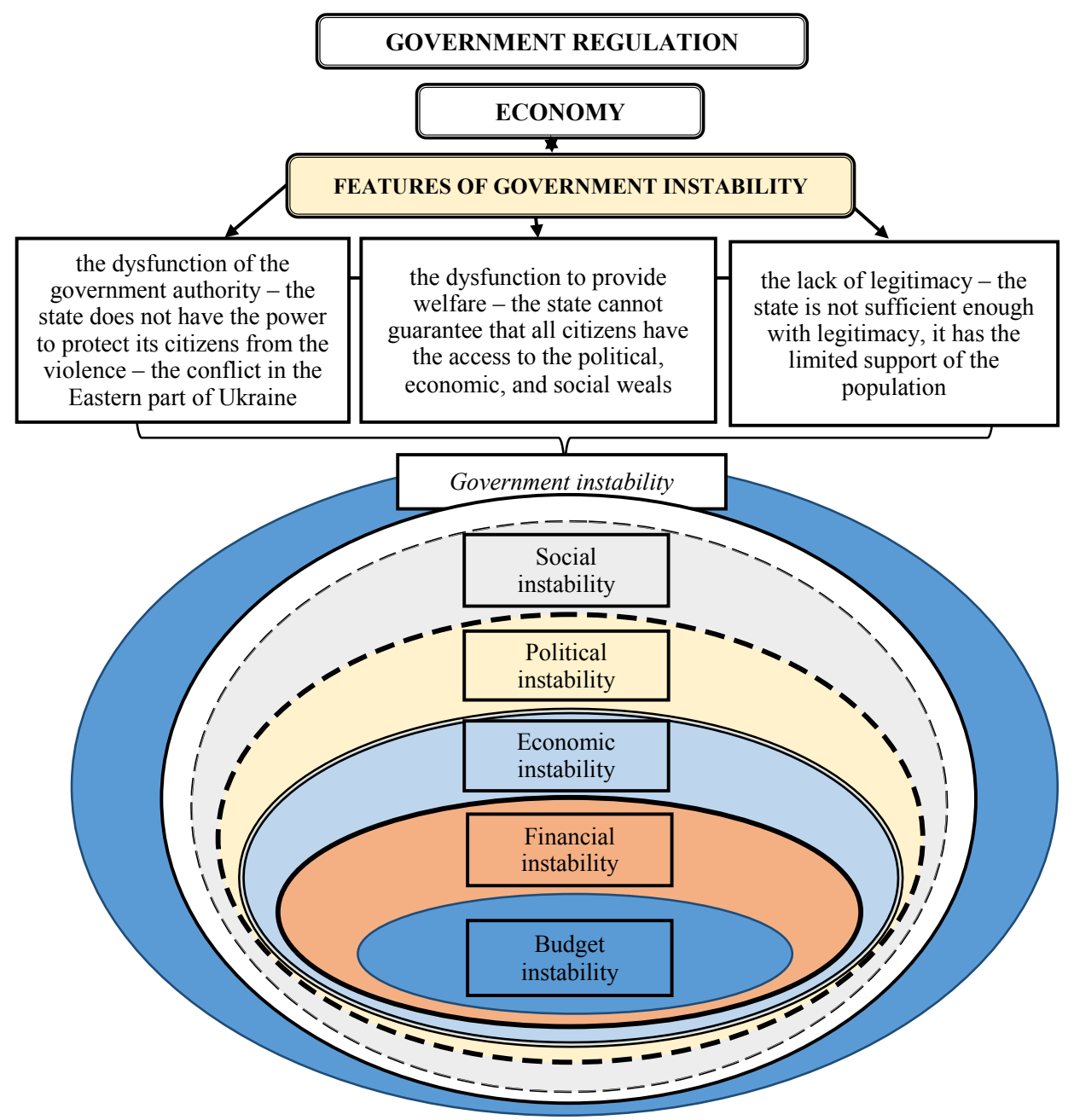

Chart 2. The role of the budget instability in the system of the government regulation in Ukraine Source: proposed by the authors 
indexes: country's incapacity, social progress, happiness, corruption's awareness, budget clarity, as well as the global index of terrorism. The data given in the Chart 3 can clearly explain that Ukraine does not the leading position. In comparison to 2018, Ukraine lost in 2018: 5 positions of country's incapacity; 6 - the global index of terrorism; 1 - index of social progress, 9 - index of happiness. The positive moment is that Ukraine increases the index of corruption's awareness to one position, and the index of budget clarity to 15 positions (when comparing 2017 to 2015 ).

The research of the global rating and the comparison of its results with the graphic interpretation of the global instability helped to assume that Ukraine has the low level of the government instability. There are a great number of problems at such level. They influence the economic development of the state. We propose to distinguish and classify problems that exist in the economy into five groups according to the types of instability (Chart 4).

The first group includes problems of budget instability (fiscal deficit, the growth of the state debt, the imperfection of the budget planning). The second group includes problems of financial instability: the growth of the bankrupt enterprises, selling up assets for the much lower price, reduction of output, decrease of deposits.

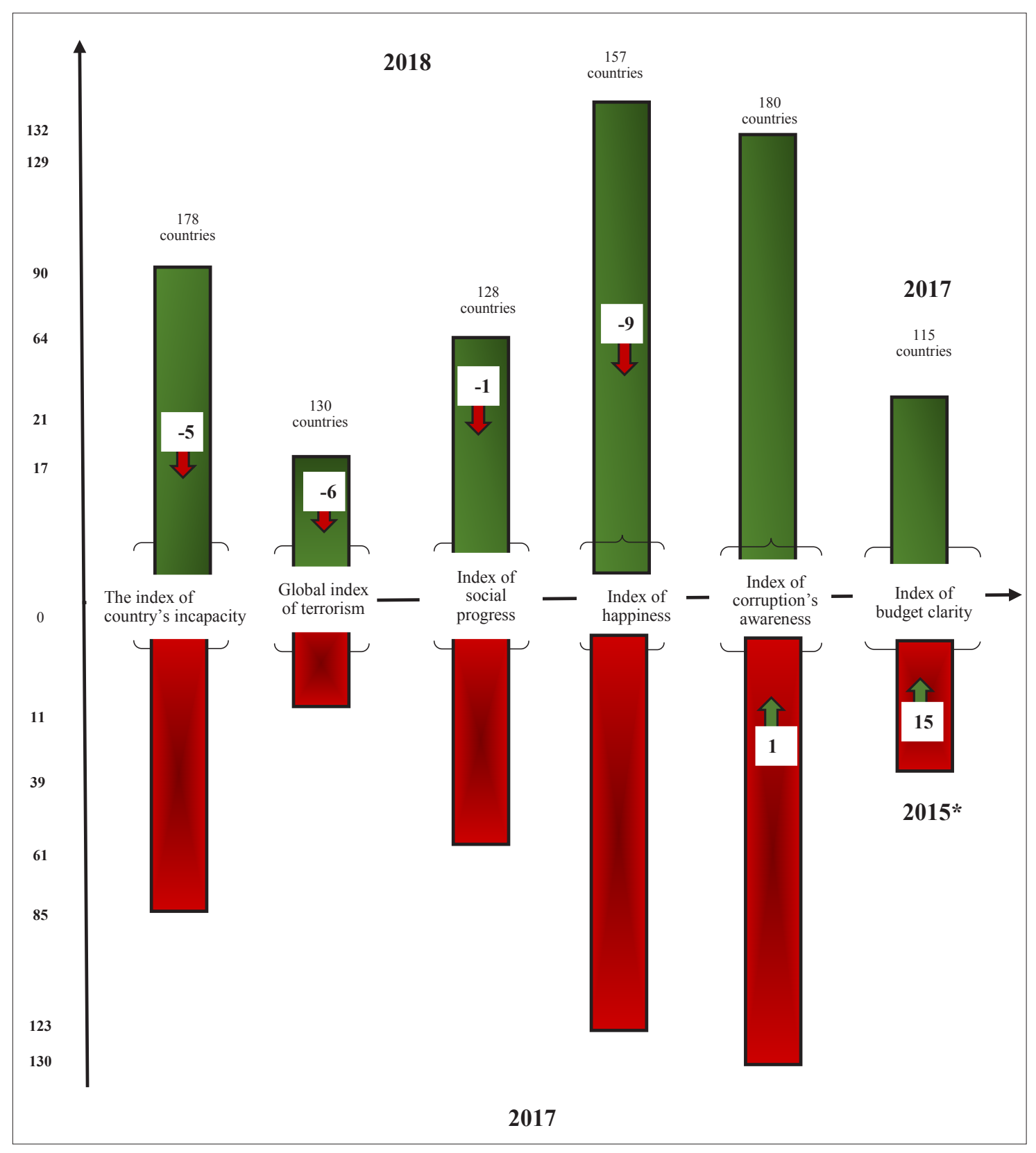

Chart 3. The Ukrainian position according to the global rating (2017-2018)

* done by independent experts in every two years 
The second group includes problems that occur as a result of the economic instability (the balance of payments deterioration, the reduction of GDP in dollar's equivalent, the black sector of the economy, the high level of inflation, corruption, the volume of GDP is behind of the real one).

Problems of social instability are in the third group. We propose to take the following factors: the decrease of the population employment, the poverty of the bigger part of the population, the increase of the population unemployment, the low level of real salaries.
The fourth group comprises problems that occur as a result of the political instability. It includes: not finished restructuring of the judicial system, the annexation of the Autonomous Republic of the Crimea, the war in the Eastern part of Ukraine.

Such an approach gives the possibility to analyse the main problems of the economic development of the state. They are based on five groups according to the defined types of the government instability (budget, financial, economic, political, social) and are connected with the analysis of the influence of the ineffective government regulation on the management with budgetary funds.

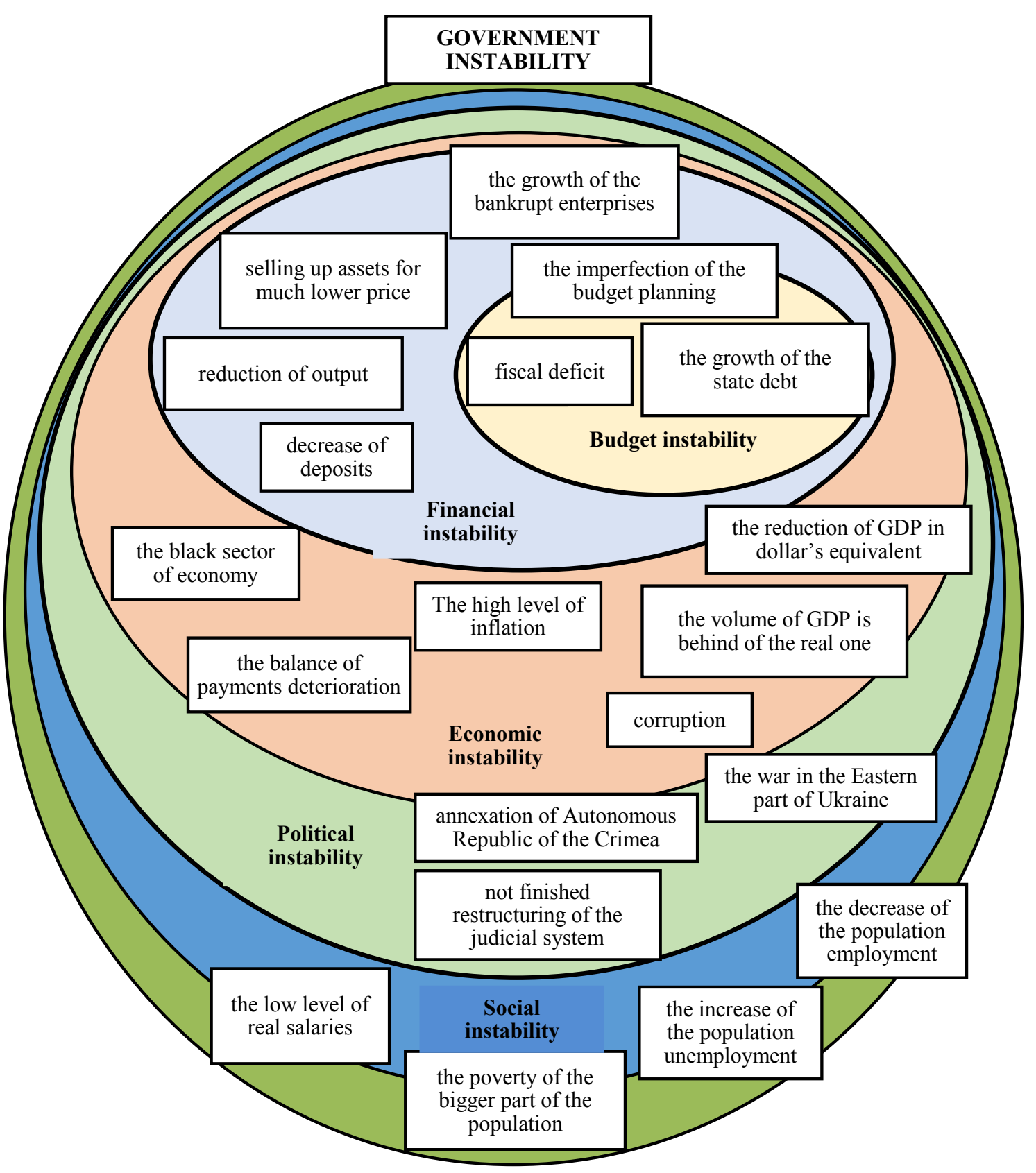

Chart 4. Consequences of the instability and its ineffective government regulation 


\section{Conclusions}

It has been proved that instability is the condition of the system characterized by the variation that happened through breaking the existing interconnection in it. The instability is that basic feature that characterizes all social and economic processes. The danger occurs when the level of instability in the state exceeds some standards.

We determined political, economic, social, financial, and budget instabilities, as well as gave the authors' definition of these phenomena after distinguishing the theoretical bases of instability. It has been proved that the government instability consists of these types. We have proposed to determine the government instability as the condition of the state characterized by the constant changes in political, economic, social, financial, and budget spheres because of the factors that influence changes in its structure and functional characteristics accompanied by the phenomena that have a negative influence on the state development in general.

The indexes analysis of the international rating and collation of its results with the graphic interpretation of the government instability have helped to prove that Ukraine has the low level of the government instability. It has been classified into five groups of problems in the economy. The analysis of the existing problems, the identification of their influence on the instabilities, as well as the clarification of their interconnection gave the possibility to study the influence of the unsuccessful state regulation on the management with budgetary funds.

\section{References:}

Colander D., Follmer H., Haas A., Goldberg M., Juselius K., Kirman A., Lux T., Sloth Br. (2009) The Financial Crisis and the Systemic Failure of Academic Economics. Kiel Working Paper 1489, 2, 246.

Crockett A. (1997) The Theory and Practice of Financial Stability. GEJ Newsletter Issue. Global Economic Institutions, 6, 23-27.

Fisher I. (1933) The Debt-Deflation Theory of Great Depression. Econometrica, 1, 337-357.

Guttentag J., Herring R. (1984) Credit rationing and financial disorder. Journal of Finance, 39, 1359-82.

Hyman Minsky P. (1992) The Financial Instability Hypothesis. Working Paper, 74.

Mishkin F. (1996) Understanding of Financial Crises: A Developing Country Perspective, NBER Working Paper 5600, 432.

Roger W. Ferguson (2008) Prepared for delivery at the East Hanover Area Chamber of Commerce. East Hanover, New Jersey, 1, 15.

Schinasi G.J. (2004) Defining Financial Stability, IMF Working Paper. International Monetary Fund, 187, 18.

Shroeder S., Schroeder S. (2009) Defining and detecting financial fragility: New Zeland's experience, International Journal of Social Economics, 36, 3, 287-307.

Burlachkov V. (2009) Theoretical bases of monetary and credit policy and World financial crisis, Economy of Ukraine, 2, 49-59.

Vasylchenko Z. (2005) Structural disproportions in the development of the bank system in Ukraine. Finances of Ukraine, 9, 140-150.

Heiets V. (2000) Instability and economic growth. Institute of economic forecasting, 344.

Hrabchuk O. (2012) Sources of instability in the development of national economy in Ukraine. Union of sciences: a scientist to a scientist: materials of the VII International scientific-practical conference, Vol. 6, 80-83.

Canes J. M. (1993) A general theory of employment, percentage and money. Econov, 486.

Kirman A., Kolander D., Phelmer H., Haas A. (2010). Financial crisis and gaps in modern Economic Science. Problems of economy, 6. 10-25.

Klymko H. (1999) Bases of economic theory: political economic aspect. Higher School, 743.

Konstantynova O. (2013) Global financial instability: variants of approaches to the definition. Retrieved from: http://www.investplan.com.ua/pdf/16_2013/23.pdf

Popov I. (2012) Methodical approaches to the determination of the financial system stability. Retrieved from: http: / / www.economy.nayka.com.ua/ ?op $=1 \& z=1177$

Rudnytska O. (2011) The analysis of the reasons for financial-economic crisis in the national economy. Vernadskiy Library. Retrieved from: http://www.nbuv.gov.ua/portal/soc_gum/Evu/2011_17_2/ Rudnyts'ka.pdf.

Stability/instability of the political system as the dynamics index of political conflicts (2011). Retrieved from: http://lib.chdu.edu.ua/pdf/naukpraci/politics/2011/175-163-15.pdf

Sumarokov V. (1996) National finances in the system of macro-economic regulation. Finances and Statistics, 224.

Trunin P., Khamenskyh M. (2007) Monitoring of financial stability in the developing economy (the example of Russia). IEPP, 5.

Ukraine in global ratings 2017-2018 (2018). Retrieved from: http://uifuture.org/uk/post/ukraina-u-globalnihrejtingah-2017-2018_691 